\title{
Pharmacology, Systematic Review and Recent Clinical Trials of Metadoxine.
}

\author{
Mathieu Di Miceli, Ph.D. ${ }^{1,2,3}$ \& Benjamin Gronier, Ph.D. ${ }^{1}$
}

${ }^{1}$ Department of Neuropharmacology

Leicester School of Pharmacy

De Montfort University

The Gateway

Leicester

LE1 9BH

United Kingdom

${ }^{2}$ Corresponding author:

Dr. Mathieu Di Miceli - mathieu.di-miceli@inra.fr

${ }^{3}$ Current affiliation :

NutriNeuro Laboratory

UMR INRA 1286 - Université de Bordeaux

Bâtiment UFR Pharmacie - 2ème Tranche - 2ème Etage - CC34

Université de Bordeaux, site de Carreire

146 rue Léo Saignat

33076 Bordeaux Cedex

France

ORCID - Mathieu Di Miceli - 0000-0003-3713-0370.

ORCID - Benjamin Gronier - 0000-0001-8107-2070. 


\begin{abstract}
$\underline{\text { Background }}$

Metadoxine is composed of pyroglutamic acid and vitamin B6. Administrations of metadoxine are indicated in cases of acute alcohol intoxication or in chronic alcoholism.
\end{abstract}

\title{
$\underline{\text { Objectives }}$
}

To reference all available clinical trials investigating the effects of metadoxine on humans. A focus was put on alcohol intoxication and chronic alcoholism, alcohol abstinence and survival rates. Adverse events were also taken into consideration. Finally, potential roles of metadoxine in treating disorders of the central nervous system will be assessed.

\section{$\underline{\text { Methods }}$}

PRISMA guidelines were followed. Computerised literature searches were performed in July 2017 to retrieve all clinical trials investigating metadoxine from the MEDLINE®, the European Union Clinical Trials Register and the ClinicalTrials.gov databases, using the following equation: "metadoxine". Inclusion criteria were all published clinical trials investigating metadoxine in humans, regardless of outcome measures. Exclusion criteria were articles not abstracted, in vitro studies, studies in rodents, retrospective studies and reviews.

\section{$\underline{\text { Results }}$}

Sixteen studies were included. Evidence suggests that metadoxine appears safe to use, as it rarely induced adverse events (reported in 7 out of the 7 studies measuring safety/tolerability). Moreover, metadoxine seems efficient in treating acute alcohol intoxication (2/2 studies) as well as improving liver functions following chronic alcoholism (4/5 studies). Finally, currently on-going clinical trials will reveal if metadoxine could be indicated in attention deficit and hyperactivity disorders as well as fragile X syndrome.

\section{Conclusion}

Metadoxine appears safe to use and seems efficient to improve liver functions following alcohol-related diseases. Further clinical trials will be necessary to determine if metadoxine can be promising for treating brain disorders. PROSPERO registration number: CRD42017072964.

Keywords: Metadoxine, systematic review, alcoholism, ADHD, fragile X syndrome, clinical trials. 


\section{1- Introduction}

Metadoxine is synthesised in vitro by salification (crystallisation) of two molecules. As shown in Figure 1, the chemical formula is composed of an ion pairing between L-2-pyrrolidone5-carboxylate (pyroglutamic acid) and pyridoxine (a form of vitamin B6) [1,2]. In metadoxine, pyroglutamic acid and vitamin B6 (1:1 ratio) have been shown to act synergically [1]. Although not physically bound, both vitamin B6 and pyroglutamic acid are electrically linked via an ion-pair salt to form metadoxine (Figure 1). Here, "salt" refers to the chemical interaction between an anion and a cation, respectively formed by pyroglutamic acid (acid, negatively charged) and vitamin B6 (base, positively charged).

Vitamin B6 is found in many food items such as cereals, fish, starchy vegetables, non-citrus fruits, egg yolks and pork [3-5]. As a co-enzyme, vitamin B6 can perform decarboxylation, transamination, deamination, racemization and desulfhydration reactions [6]. Furthermore, vitamin B6-dependent pathways include glycogenolysis, the synthesis of several neurotransmitters (dopamine, epinephrine, norepinephrine, gamma aminobutyric acid and serotonin) as well as several endogenous compounds such as taurine, histamine, ceramide and haemoglobin [7-10]. Figure 2 summarises non-exhaustively the metabolic pathways involving vitamin B6 (as pyridoxal 5'phosphate, its active form).

Pyroglutamic acid was discovered in 1882 by Haitinger as being the result of heating glutamate to $180^{\circ} \mathrm{C}$. It is found at the centre of both glutamate and glutamine metabolisms [11], as seen in Figure 3. Moreover, pyroglutamic acid is a naturally-occurring amino acid found in a few food items such as parmesan [12] and yoghurt [13]. Under artificial conditions (acidic, alkaline or 
temperatures above $78^{\circ} \mathrm{C}$ ), glutamate and glutamine can spontaneously transform into pyroglutamic acid [14-16]. Such results could explain the presence of pyroglutamic acid in some diets as a result of heating glutamate/glutamine-rich food [17]. Pyroglutamic acid can be dosed in aqueous compartments such as the cerebrospinal fluid and urine, with respective levels of 0.06 and 0.19 $\mu$ moles/ml [18]. Interestingly, in human serum, spontaneous cyclisation of glutamine can lead to the formation of pyroglutamic acid [15]. Finally, pyroglutamic acid is also found at concentrations below $10 \mu \mathrm{M}$ in human serum [15,19] and several other organs in the rat, guinea pig and rabbit, such as the lungs, the heart, the liver, the spleen and the brain [18].

In humans, metadoxine has a short half-life, ranging between 40 to 60 minutes when given orally or intravenously $[1,20]$. Bioavailability is considered high, as pharmacokinetic studies have demonstrated a range of $60-80 \%$, with wide tissue distribution [1]. Excretion is performed equally through urine and faeces [1]. Dosing regimens can vary largely. Indeed, doses of metadoxine administered to patients depend entirely upon the physiopathology they are intended for, and will thus be discussed later. Side effects following metadoxine treatments remain rare.

Alcohol is a widely used psychoactive drug, mostly in western countries [21,22]. The psychoactive effects of alcohol are attributed to the concentration of ethanol in alcoholic beverages [23]. Ethanol metabolism is more efficient in the liver than in the stomach, due to greater levels of alcohol metabolising enzymes in the liver [24,25]. Moreover, gastric first-pass metabolism accounts for $10 \%$ of total alcohol metabolism, while the remaining $90 \%$ occurs in the liver [22]. Ethanol consumption leads to enhanced hepatic levels of cytochrome P-450 [26-29]. Ethanol can be degraded by two different pathways. On the one hand, the cytochrome P-450 CYP2E1 converts ethanol into acetaldehyde in the endoplasmic reticulum [25], leading to the formation of reactive 
oxygen species. On the other hand, ethanol can be degraded into acetaldehyde by the alcohol dehydrogenase route in the liver [30,31]. While alcohol dehydrogenase accounts for "essentially all" alcohol metabolism (low $\mathrm{K}_{\mathrm{m}}: 0.2-2 \mathrm{mM}$ ), CYP2E1 is involved when alcohol concentrations are high (high $\mathrm{K}_{\mathrm{m}}: 8-10 \mathrm{mM}$ ) [32]. However, CYP2E1 is a major metabolic pathway for ethanol oxidation in the central nervous system [33]. Chronic alcohol intake generates toxic acetaldehydes, resulting from altered ethanol degradation pathways [30]. The consequences of chronic alcoholism include fatty liver disease, cirrhosis and alcoholic hepatitis [34].

Metadoxine has been shown to play a crucial role in the regulation of GABA neurotransmission [35], the dysregulation of which has been closely linked to attention deficit and hyperactivity disorder (ADHD) [36-39]. Fragile X syndrome was first suspected in 1943 by Martin and Bell [40]. Characterised by mental retardation, it is caused by expansion of a CGG trinucleotide in the locus Xq27.3 on the X chromosome [41,42]. Such a mutation inhibits the FMR1 gene (fragile X mental retardation 1), which, in turn, disrupts the FMR protein, involved in the downstream signal of glutamate and responsible for the stabilisation of protein translation [42]. In fine, such a mutation alters both glutamate and GABA neurotransmissions [43-46].

Because metadoxine is a simple combination of vitamin B6 and pyroglutamic acid, our objective is to provide an insight of how such basic molecules could benefit a wide range of patients, being admitted in clinics for acute illness to life-threatening diseases. This systematic review will assess the main outcomes of all clinical trials using metadoxine. 


\section{2- Material and Methods}

We followed the PRISMA guidelines (Preferred Reporting Items for Systematic Reviews and MetaAnalyses) [69]. This review protocol has been registered in the International Prospective Register of Systematic Reviews (PROSPERO) with the registration number CRD42017072964 and can be accessed at the following URL address:

http://www.crd.york.ac.uk/PROSPERO/display_record.php?ID=CRD42017072964

\section{Eligibility and exclusion criteria}

Eligible studies were all published trials investigating metadoxine in humans, regardless of regimen, length and outcomes. Exclusion criteria were studies not abstracted, studies performed on rodents, in vitro studies, retrospective studies and review articles. Studies not written in English were only included if abstract was translated into English.

\section{$\underline{\text { Information sources and search methods }}$}

Computerised literature searches were performed in three different databases: MEDLINE@, the European Union Clinical Trials Register and the ClinicalTrials.gov registry. We used the single word "metadoxine" as the search equation in late July 2017 for our systematic review. To access some studies, some corresponding authors, listed in the abstracts, were directly contacted. 


\section{$\underline{\text { Data items }}$}

Essential information extracted from all studies included: 1- trial type (if applicable), 2location, 3- physiopathologies of enrolled patients, 4- number of patients enrolled in both metadoxine and control groups (if applicable), 5- number of adverse events (if applicable), 6- main outcome(s), and 7- possible bias.

\section{$\underline{\text { Risk of bias in individual studies }}$}

All included studies were evaluated by the reviewers. As suggested by the Cochrane Collaboration handbook [47] and the GRADE framework, risks of bias for each study were examined as follows: 1- random sequence generation (selection bias), 2- allocation concealment, 3blinding, 4- Accounting of patients and outcome events, 5- selective reporting, and 6- overall risk of bias. Please refer to Table 2 for risk of bias across the included studies.

\section{$\underline{\text { Summary measures }}$}

Outcomes consisted of efficacy, adverse effects, survival rates and improvement of symptoms, regardless of pathologies. Efficacy was defined as improved symptoms compared to placebos or reference drugs. Adverse effects (or adverse events) were defined as the appearance of one (or more) untoward symptom(s). Survival rates were measured as the proportion of patients still alive at the time of measurement, usually charted on Kaplan-Meier diagrams. 


\section{3- Results}

\section{$\underline{\text { Selection of studies }}$}

Figure 4 shows the flow diagram of study design. With the search equation, 66 studies were identified through the MEDLINEC database, all of which were assessed for eligibility. Out of those initial 66 studies, 50 were excluded according to the exclusion criteria. Indeed, 18 studies were performed on rodents [48-65], 4 were in vitro studies [66-69], 10 studies had no abstracts [70-79], 13 were review articles [1,22,80-90], 2 studies were performed retrospectively [91,92] and 3 studies were excluded after assessment for eligibility, due to the unavailability of these articles, the written languages or insufficient details within abstracts [93-95]. Out of the initial 13 studies from the ClinicalTrials.gov database, 10 were excluded, among which two are still recruiting and eight have no available results. Therefore, 19 studies were eligible for review. However, 3 studies were present in duplicates and were therefore removed from eligibility. Finally, a total of 16 studies were included in the present review (Figure 4).

\section{$\underline{\text { Characteristics of studies }}$}

Table 1 presents all the extracted information. In total, 731 patients were enrolled in the metadoxine group while 721 were enrolled in the control group. However, a further 36 patients were given metadoxine without being compared to the appropriate controls [96], giving rise to some bias concern. Sixty patients were enrolled in the study by Rizzo and colleagues, but we did not find further information about subgroup numbers, although patients receiving metadoxine were indeed compared to patients receiving placebos [97]. Acute doses of metadoxine varied from 300 to 900 mg while doses chronically administered ranged from 500 to $2000 \mathrm{mg} /$ day over 10 to 90 days. Routes of administration were different according to pathologies. Indeed, intravenous metadoxine 
was used for acutely administered metadoxine for patients under alcohol intoxication, while per os administration was preferred for long-term treatment. Note that infusion of metadoxine was used in one study [35]. Interestingly, one study [98] used washout periods to determine how attention may improve after a single dose of metadoxine (700 to $1400 \mathrm{mg}$ ). Whether such a study can be considered as using a chronic metadoxine protocol is an open question. Among all the studies, pathologies varied from chronic alcoholism, acute alcohol intoxication, alcoholic and non-alcoholic hepatitis, alcohol liver disease, to attention deficit and hyperactivity disorder. Main outcomes are summarised in Table 1.

\section{$\underline{\text { Risk of bias within studies }}$}

Nine trials used a randomized and double-blind technique. Two trials were not randomised in design [2,96]. Four studies were designed as open-label protocols [99-102]. One study did not compare patients receiving metadoxine to patients receiving placebos and may therefore introduce some degree of bias [96].

\section{$\underline{\text { Synthesis of results }}$}

Table 1 summarises all main outcome of the 16 studies included within the present systematic review.

Risk of bias is displayed in Table 2 .

Table 3 presents the exhaustive list of clinical trials $(n=13)$ registered in the ClinicalTrial.gov database, as of late July 2017. Note that two trials are still recruiting patients suffering from non-alcoholic steatohepatitis. A minority of these clinical trials $(n=3)$ have published results. Two trials have available but not yet published results. These results can be accessed through 
the database tabular. Note that a phase III clinical trial on ADHD patients (NCT02477748) was terminated by the Food and Drug Administration (FDA, U.S.A.) due to possible adverse events. However, it was argued that previous studies found opposite results (see discussion below). Results on Fragile X syndrome are not yet available (NCT02126995).

\section{4- Discussion}

Only one drug-induced side effect has been reported in humans in the form of a skin rash [103]. Therefore, metadoxine has been considered safe to use by some $[91,99,100]$. The safety of metadoxine seems to have been ascertained, although some adverse events were reported.

In healthy volunteers, metadoxine reduced the half-life of ethanol [1]. After acute alcohol intoxication, metadoxine (300 mg/kg, intravenously) improved at least one degree of intoxication in 17 out of 26 patients presenting clinical signs of alcohol intoxication [100]. Another clinical study has shown that a single intravenous metadoxine administration $(900 \mathrm{mg}$ ) significantly decreases the half-life of ethanol in the blood (from 6.7 hours to 5.4 hours) [103]. As an immediate consequence, the authors therefore witnessed faster recovery rates in metadoxine-treated patients than in placebotreated patients (respectively under 1 hour and over 2 hours). In another study using a similar protocol, metadoxine given intravenously as a bolus at a dose of $300 \mathrm{mg}$ (with a second identical dose only if necessary) improved somatic and psychological symptoms of patients presenting acute alcohol intoxication in the emergency room [22].

In chronic alcoholism, liver functions are impaired [34,104]. In a study involving 136 alcoholic patients, $1500 \mathrm{mg} /$ day (divided into 3 daily doses) of metadoxine for 90 days significantly 
improved liver functions quicker than placebos [105]. As a matter of fact, improved liver functions were here characterised by decreased degrees of steatosis (abnormal retention of lipids), decreased serum levels of bilirubin, gammaglutamyl transpeptidase, cholesterol and triglycerides. Such results were also confirmed in another clinical trial including 75 patients receiving $1000 \mathrm{mg} /$ day of metadoxine, split into 2 daily doses [106]. Alcohol abstinence was, alone, sufficient in improving liver functions in two other studies $[73,105]$. In another study, authors concluded that metadoxine allows a faster recovery through restored hepatic glutathione levels as well as enhanced oxidation of both ethanol and acetaldehyde, based upon their pre-clinical results [105,107]. Another laboratory found that 10 days of metadoxine treatment (1800 mg/day via two saline infusions) directly improved abstinence, reducing therefore the need for benzodiazepine therapy [35]. It should be noted that abstinence remains the most important therapeutic measure for improved liver functions, as others have agreed [73].

In an open-label study, $1500 \mathrm{mg} /$ day of metadoxine was associated with other frequentlyused molecules to determine survival rates of patients suffering from severe alcoholic hepatitis [102]. A 30-day co-administration treatment of metadoxine (1500 mg/day, in 3 daily doses) with either prednisone (40 mg/day, once daily) or pentoxifylline (1200 mg/day, in 3 daily doses) significantly improved survival rates at 3 and 6 months, compared to patients only receiving prednisone or pentoxifylline. Interestingly, patients receiving the combined therapy were able to maintain greater abstinence than those receiving monotherapy [102], as observed in older studies $[2,97]$. Another clinical trial, using the same protocol, led to similar results, but this study also revealed the reduced development of encephalopathy and hepatorenal syndrome as well as improved responses to treatments for patients receiving the combined therapy [101]. 
Because greater alcohol abstinence was observed in patients under metadoxine therapy, probable metadoxine-induced anti-craving effects were suspected [2,64,92,97]. Such effects, if clearly demonstrated, may be mediated in the central nervous system. Ethanol disrupts neuronal excitability via complex ionic modulations of synaptic currents. Indeed, ethanol can target voltagegated and dihydropyridine-sensitive calcium channels, gamma aminobutyric acid (GABA) receptors, adenosine receptors and transporters, G protein-coupled inwardly-rectifying potassium channels (GIRKs) as well as N-methyl-D-aspartate (NMDA) receptors [108-115]. Therefore, the effects of metadoxine on the central nervous system (CNS) were also investigated in different pathologies, such as ADHD and Fragile X syndrome.

Among the worldwide population, ADHD affects 6-7\% of children if diagnosed via the Diagnostic and Statistical Manual of Mental Disorders, fourth edition [116]. The prevalence of ADHD in the US child population has been estimated at $8.7 \%$ [117], a rate that is very similar to the UK figure of $8 \%$ of school-aged children [118]. Current pharmacotherapy for ADHD can induce adverse events [119-123]. Core ADHD symptoms include inattention, hyperactivity as well as impulsivity $[124,125]$. Such symptoms were found to be significantly improved following metadoxine treatment ( 6 weeks of $1400 \mathrm{mg} /$ day, comprised of $490 \mathrm{mg} /$ day of immediate release and $910 \mathrm{mg} /$ day of extended release), or even after a single $1400 \mathrm{mg}$ acute administration [98,126,127]. Following acute metadoxine intake, such effects lasted from 3 to 5 hours. Under chronic metadoxine treatment, the effects were found to be significant after 2 weeks and lasted until the treatment was terminated. However, a single dose of $700 \mathrm{mg}$ of metadoxine was insufficient to improve ADHD scores [98]. It is known that ADHD patients present decreased GABA levels in both the somatosensory and motor cortices [128] as well as up-regulated GABAergic inhibitory functions in frontal, temporal and cingulate regions [129]. Moreover, prefrontal and cingulate glutamate neurotransmissions were altered in ADHD patients [130,131]. A unique advantage to treating 
ADHD patients with metadoxine resides in its pharmacological properties. Indeed, compared to already approved ADHD medication, metadoxine does not involve the blockade of neurotransmitter uptake nor psychostimulation. Its ability to improve cognition may be interesting in other diseases involving cognitive impairments such as Alzheimer's and Parkinson's diseases as well as schizophrenia. We believe that the effects of metadoxine on ADHD symptoms could be attributed to the roles of both vitamin B6 and pyroglutamic acid in replenishing GABA and glutamate levels, respectively. Indeed, as seen in Figure 2, increases in the cellular content of vitamin B6 could lead to increases in GABA levels. Similarly, Figure 3 shows that pyroglutamic acid can be transformed into glutamate by 5-oxoprolinase, thus increasing cellular content of glutamate. Furthermore, studies performed on animals have shown that pyroglutamic acid can increase GABA levels in the frontal cortex [132].

Metadoxine was investigated in a phase II study, comparing its efficacy to placebo in alleviating the physiopathology of Fragile X syndrome (NCT02126995). In this study, adults and adolescents were given 700-1400 mg/day of metadoxine in a randomised fashion for a total of 6 weeks. Outcome measures will focus on safety and the severity of syndromes. The results are yet to be disclosed. Until 2016, this new molecule for ADHD treatment was still under investigation. Unfortunately, early in 2017 and following a phase III clinical trial, metadoxine was believed to be inefficient for ADHD patients. However, 4 trials investigating metadoxine in ADHD patients have not yet disclosed results (NCT02126995, NCT00995085, NCT02189772 and NCT02059642). Based upon the Conners' Adult ADHD Rating Scale (CAARS), 10 weeks of metadoxine (1400 $\mathrm{mg}$ /day) failed to bring about significantly different results from the placebo in the 293 patients enrolled for a trial. Besides, a retrospective analysis of adverse neurological events with metadoxine in rodents has resulted in a full clinical hold of the phase III trial by the FDA (ClinicalTrials.gov identifier NCT02477748). This measure came as a surprise and researchers have argued that 
metadoxine has gone through many clinical trials and side effects never occurred more frequently or severely than with placebos [127]. Finally, another interest for the use metadoxine is found in ADHD patients with alcohol abuse [82], because of its efficiency in treating alcohol abuse, as mentioned earlier. Indeed, alcohol abuse is a frequently observed co-morbidity in adults and children with ADHD [133-136].

Since all studies presented in this review included rather small sample sizes, a major limitation to all findings resides in the fact that these trials are likely to report large beneficial effects, compared to studies with greater sample sizes [137]. Thus, caution should be taken in the interpretation of results arising from small trials.

\section{4- Conclusion}

To conclude, metadoxine seems efficient in treating acute and chronic alcohol exposure, probably due to increased ethanol metabolism. Moreover, its efficacy in reducing steatosis and hepatorenal syndromes has been clearly demonstrated, combined with improved survival rates. Metadoxine is currently under investigation for its potential benefits in ADHD and fragile X syndrome. Side effects are not more frequently or more severely observed than those observed using placebos or other approved drugs. Future fundamental and clinical studies will be needed for the complete understanding of the effects of metadoxine on liver and brain functions, as well as determining precise cellular mechanisms. While the efficacy of metadoxine in treating alcohol dependence and alcohol-induced liver damage has been ascertained in international studies, its efficacy in treating CNS disorders remains unclear. 


\section{Registration of this review}

This review protocol has been registered in the International Prospective Register of Systematic Reviews (PROSPERO) with the registration number CRD42017072964 and can be accessed at the following URL address:

http://www.crd.york.ac.uk/PROSPERO/display_record.php?ID=CRD42017072964

\section{Acknowledgements}

The authors wish to thank both Dr. Willy Joly (Ph.D.) and Dr. Romain Ragimbeau (M.D.) for critical comments, as well as Dr. Caroline Di Miceli (Ph.D.) for language editing.

\section{Conflict of interest}

Authors declare that they have no conflict of interest.

\section{Funding}

This study was not supported by any grant/fund. 


\section{References}

1. Addolorato G, Ancona C, Capristo E, Gasbarrini G. Metadoxine in the treatment of acute and chronic alcoholism: a review. Int J Immunopathol Pharmacol. 2003 Dec;16(3):207-14.

2. Guerrini I, Gentili C, Nelli G, Guazzelli M. A follow up study on the efficacy of metadoxine in the treatment of alcohol dependence. Subst Abuse Treat Prev Policy. 2006 Dec 18;1:35.

3. Stover PJ, Field MS. Vitamin B-6. Adv Nutr Bethesda Md. 2015 Jan;6(1):132-3.

4. Esteve MJ, Farré R, Frígola A, García-Cantabella JM. Determination of vitamin B6 (pyridoxamine, pyridoxal and pyridoxine) in pork meat and pork meat products by liquid chromatography. $\mathrm{J}$ Chromatogr A. 1998 Feb 6;795(2):383-7.

5. Vedrina-Dragojević I, Sebecić B. Effect of frozen storage on the degree of vitamin B6 degradation in different foods. Z Lebensm Unters Forsch. 1994 Jan;198(1):44-6.

6. Ebadi M. Regulation and function of pyridoxal phosphate in CNS. Neurochem Int. 1981;3(34):181-205.

7. Petroff OAC. GABA and glutamate in the human brain. Neurosci Rev J Bringing Neurobiol Neurol Psychiatry. 2002 Dec;8(6):562-73.

8. Schousboe A, Waagepetersen HS. GABA: homeostatic and pharmacological aspects. Prog Brain Res. 2007;160:9-19.

9. Gault CR, Obeid LM, Hannun YA. An overview of sphingolipid metabolism: from synthesis to breakdown. Adv Exp Med Biol. 2010;688:1-23.

10. Obeid OA, Johnston K, Emery PW. Plasma taurine and cysteine levels following an oral methionine load: relationship with coronary heart disease. Eur J Clin Nutr. 2004 Jan;58(1):105-9.

11. Kumar A, Bachhawat AK. Pyroglutamic acid: throwing light on a lightly studied metabolite. Curr Sci. 2012;102(2):288-97.

12. Mucchetti G, Locci F, Gatti M, Neviani E, Addeo F, Dossena A, et al. Pyroglutamic acid in cheese: presence, origin, and correlation with ripening time of Grana Padano cheese. J Dairy Sci. 2000 Apr;83(4):659-65.

13. Mochizuki T, Todoroki K, Inoue K, Min JZ, Toyo'oka T. Isotopic variants of light and heavy Lpyroglutamic acid succinimidyl esters as the derivatization reagents for DL-amino acid chiral metabolomics identification by liquid chromatography and electrospray ionization mass spectrometry. Anal Chim Acta. 2014 Feb 6;811:51-9.

14. Kumar M, Chatterjee A, Khedkar AP, Kusumanchi M, Adhikary L. Mass spectrometric distinction of in-source and in-solution pyroglutamate and succinimide in proteins: a case study on rhG-CSF. J Am Soc Mass Spectrom. 2013 Feb;24(2):202-12.

15. Nagana Gowda GA, Gowda YN, Raftery D. Massive Glutamine Cyclization to Pyroglutamic Acid in Human Serum Discovered Using NMR Spectroscopy. Anal Chem. 2015 Apr 7;87(7):3800-5.

16. Park CB, Lee SB, Ryu DD. L-pyroglutamate spontaneously formed from L-glutamate inhibits growth of the hyperthermophilic archaeon Sulfolobus solfataricus. Appl Environ Microbiol. 2001 Aug;67(8):3650-4. 
17. Ueda Y, Yonemitsu M, Tsubuku T, Sakaguchi M, Miyajima R. Flavor characteristics of glutathione in raw and cooked foodstuffs. Biosci Biotechnol Biochem. 1997 Dec;61(12):1977-80.

18. Wilk S, Orlowski M. The occurrence of free L-pyrrolidone carboxylic acid in body fluids and tissues. FEBS Lett. 1973 Jul 1;33(2):157-60.

19. Yi L, Shi S, Wang Y, Huang W, Xia Z, Xing Z, et al. Serum Metabolic Profiling Reveals Altered Metabolic Pathways in Patients with Post-traumatic Cognitive Impairments. Sci Rep. 2016 Feb $17 ; 6: 21320$.

20. Lü Y, Kang Z, Liu Y, Li T, Xiao Y. Pharmacokinetics of metadoxine for injection after repeated doses in healthy volunteers. Chin Med J (Engl). 2007 Jan 20;120(2):166-8.

21. Crocq M-A. Alcohol, nicotine, caffeine, and mental disorders. Dialogues Clin Neurosci. 2003 Jun;5(2):175-85.

22. Vonghia L, Leggio L, Ferrulli A, Bertini M, Gasbarrini G, Addolorato G, et al. Acute alcohol intoxication. Eur J Intern Med. 2008 Dec;19(8):561-7.

23. Most D, Ferguson L, Harris RA. Molecular basis of alcoholism. Handb Clin Neurol. 2014;125:89111.

24. Lee S-L, Chau G-Y, Yao C-T, Wu C-W, Yin S-J. Functional assessment of human alcohol dehydrogenase family in ethanol metabolism: significance of first-pass metabolism. Alcohol Clin Exp Res. 2006 Jul;30(7):1132-42.

25. Cederbaum AI. Alcohol metabolism. Clin Liver Dis. 2012 Nov;16(4):667-85.

26. Lieber CS. Alcohol, liver, and nutrition. J Am Coll Nutr. 1991 Dec;10(6):602-32.

27. Ardies CM, Zachman EK, Koehn BJ. Effect of swimming exercise and ethanol on rat liver P450dependent monooxygenases. Med Sci Sports Exerc. 1994 Dec;26(12):1453-8.

28. Djordjević D, Nikolić J, Stefanović V. Ethanol interactions with other cytochrome P450 substrates including drugs, xenobiotics, and carcinogens. Pathol Biol (Paris). 1998 Dec;46(10):760-70.

29. Kumar S, Earla R, Jin M, Mitra AK, Kumar A. Effect of ethanol on spectral binding, inhibition, and activity of CYP3A4 with an antiretroviral drug nelfinavir. Biochem Biophys Res Commun. 2010 Nov 5;402(1):163-7.

30. Lieber CS. Alcoholic fatty liver: its pathogenesis and mechanism of progression to inflammation and fibrosis. Alcohol Fayettev N. 2004 Aug;34(1):9-19.

31. Rasineni K, Casey CA. Molecular mechanism of alcoholic fatty liver. Indian J Pharmacol. 2012 May;44(3):299-303.

32. Prakash O, Nelson S. Alcohol and Liver Disease. Ochsner J. 2002;4(4):241-4.

33. Heit C, Dong H, Chen Y, Thompson DC, Deitrich RA, Vasiliou V. The Role of CYP2E1 in Alcohol Metabolism and Sensitivity in the Central Nervous System. Subcell Biochem. 2013;67:235-47.

34. Bruha R, Dvorak K, Petrtyl J. Alcoholic liver disease. World J Hepatol. 2012 Mar 27;4(3):81-90.

35. Bono G, Sinforiani E, Merlo P, Belloni G, Soldati M, Gelso E. Alcoholic abstinence syndrome: short-term treatment with metadoxine. Int J Clin Pharmacol Res. 1991;11(1):35-40. 
36. Bollmann S, Ghisleni C, Poil S-S, Martin E, Ball J, Eich-Höchli D, et al. Developmental changes in gamma-aminobutyric acid levels in attention-deficit/hyperactivity disorder. Transl Psychiatry. 2015 Jun 23;5:e589.

37. Nagamitsu S, Yamashita Y, Tanigawa H, Chiba H, Kaida H, Ishibashi M, et al. Upregulated GABA Inhibitory Function in ADHD Children with Child Behavior Checklist-Dysregulation Profile: 123IIomazenil SPECT Study. Front Psychiatry. 2015;6:84.

38. Ende G, Cackowski S, Van Eijk J, Sack M, Demirakca T, Kleindienst N, et al. Impulsivity and Aggression in Female BPD and ADHD Patients: Association with ACC Glutamate and GABA Concentrations. Neuropsychopharmacol Off Publ Am Coll Neuropsychopharmacol. 2016 Jan;41(2):410-8.

39. Purkayastha P, Malapati A, Yogeeswari P, Sriram D. A Review on GABA/Glutamate Pathway for Therapeutic Intervention of ASD and ADHD. Curr Med Chem. 2015 04;22(15):1850-9.

40. Martin JP, Bell J. A PEDIGREE OF MENTAL DEFECT SHOWING SEX-LINKAGE. J Neurol Psychiatry. 1943 Jul;6(3-4):154-7.

41. Saldarriaga W, Tassone F, González-Teshima LY, Forero-Forero JV, Ayala-Zapata S, Hagerman R. Fragile X syndrome. Colomb Medica Cali Colomb. 2014 Dec;45(4):190-8.

42. Bagni C, Tassone F, Neri G, Hagerman R. Fragile X syndrome: causes, diagnosis, mechanisms, and therapeutics. J Clin Invest. 2012 Dec;122(12):4314-22.

43. Bear MF, Huber KM, Warren ST. The mGluR theory of fragile X mental retardation. Trends Neurosci. 2004 Jul;27(7):370-7.

44. Centonze D, Rossi S, Mercaldo V, Napoli I, Ciotti MT, De Chiara V, et al. Abnormal striatal GABA transmission in the mouse model for the fragile X syndrome. Biol Psychiatry. 2008 May 15;63(10):963-73.

45. Muddashetty RS, Kelić S, Gross C, Xu M, Bassell GJ. Dysregulated metabotropic glutamate receptor-dependent translation of AMPA receptor and postsynaptic density-95 mRNAs at synapses in a mouse model of fragile X syndrome. J Neurosci Off J Soc Neurosci. 2007 May 16;27(20):5338-48.

46. D'Hulst C, De Geest N, Reeve SP, Van Dam D, De Deyn PP, Hassan BA, et al. Decreased expression of the GABAA receptor in fragile X syndrome. Brain Res. 2006 Nov 22;1121(1):23845.

47. Higgins JP, Altman DG. Assessing Risk of Bias in Included Studies. In: Fellow JPHSSV, Director SGF, editors. Cochrane Handbook for Systematic Reviews of Interventions [Internet]. John Wiley \& Sons, Ltd; 2008 [cited 2017 Dec 10]. p. 187-241. Available from: http://onlinelibrary.wiley.com/doi/10.1002/9780470712184.ch8/summary

48. Parés X, Moreno A, Peralba JM, Font M, Bruseghini L, Esteras A. Action of metadoxine on isolated human and rat alcohol and aldehyde dehydrogenases. Effect on enzymes in chronic ethanol-fed rats. Methods Find Exp Clin Pharmacol. 1991 Feb;13(1):37-42.

49. Ki SH, Choi JH, Kim CW, Kim SG. Combined metadoxine and garlic oil treatment efficaciously abrogates alcoholic steatosis and CYP2E1 induction in rat liver with restoration of AMPK activity. Chem Biol Interact. 2007 Aug 30;169(2):80-90.

50. Felicioli R, Saracchi I, Flagiello AM, Bartoli C. Effects of pyridoxine-pyrrolidon-carboxylate on hepatic and cerebral ATP levels in ethanol treated rats. Int J Clin Pharmacol. 1980 Jun;18(6):27780. 
51. Calabrese V, Calderone A, Ragusa N, Rizza V. Effects of Metadoxine on cellular status of glutathione and of enzymatic defence system following acute ethanol intoxication in rats. Drugs Exp Clin Res. 1996;22(1):17-24.

52. Calabrese V, Randazzo G, Ragusa N, Rizza V. Long-term ethanol administration enhances agedependent modulation of redox state in central and peripheral organs of rat: protection by metadoxine. Drugs Exp Clin Res. 1998;24(2):85-91.

53. Arosio B, Santambrogio D, Gagliano N, Annoni G. Changes in expression of the albumin, fibronectin and type I procollagen genes in CCl4-induced liver fibrosis: effect of pyridoxol L,2pyrrolidon-5 carboxylate. Pharmacol Toxicol. 1993 Dec;73(6):301-4.

54. Muriel P, Deheza R. Fibrosis and glycogen stores depletion induced by prolonged biliary obstruction in the rat are ameliorated by metadoxine. Liver Int Off J Int Assoc Study Liver. 2003 Aug;23(4):262-8.

55. Calabrese V, Bombaci G, Calderone A, Rizza V. Effects of metadoxine on cellular free fatty acid levels in ethanol treated rats. Int J Tissue React. 1993;15(6):235-43.

56. Calabrese V, Calderone A, Ragusa N, Rizza V. Effects of metadoxine on cellular formation of fatty acid ethyl esters in ethanol treated rats. Int J Tissue React. 1995;17(3):101-8.

57. Fornai F, Grazia Alessandrì M, Bonuccelli U, Scalori V, Corsini GU. Effect of metadoxine on striatal dopamine levels in C57 black mice. J Pharm Pharmacol. 1993 May;45(5):476-8.

58. Wen D-C, Hu X-Y, Wang Y-Y, Luo J-X, Lin W, Jia L-Y, et al. Effects of aqueous extracts from Panax ginseng and Hippophae rhamnoides on acute alcohol intoxication: An experimental study using mouse model. J Ethnopharmacol. 2016 Nov 4;192:67-73.

59. Lee DY, Kang HE, Kim SG, Lee MG. Negligible effect of oral garlic oil on the oral absorption of pyridoxine in metadoxine in rats. Arch Pharm Res. 2010 Jul;33(7):1005-8.

60. Kim JY, Kim K-H, Lee YJ, Lee SH, Park JC, Nam DH. Oenanthe javanica extract accelerates ethanol metabolism in ethanol-treated animals. BMB Rep. 2009 Aug 31;42(8):482-5.

61. Zhu H-J, Ke X-Q, Zhu X-Q, Zheng Y-F, Shi H, Xue Z-Y. [Study on the mechanism of male reproductive toxicity of metadoxine in mice and rats]. Zhonghua Yu Fang Yi Xue Za Zhi. 2004 Jul;38(4):269-72.

62. Wang Y, Zhu H, Lai W, Chen J, Mei S, Zhang W, et al. [Reproductive toxicity of metadoxine in rats]. Zhonghua Yu Fang Yi Xue Za Zhi. 2003 May;37(3):178-82.

63. Garau B, Fadda F, Melis F, Gelso E, Gessa GL. Metadoxine (pyrrolidone carboxylate of pyridoxine) antagonizes the locomotor-stimulatory effect of ethanol in mice. Alcohol Alcohol Oxf Oxfs. 1992 Sep;27(5):501-4.

64. Annoni G, Contu L, Tronci MA, Caputo A, Arosio B. Pyridoxol L,2-pyrrolidon-5 carboxylate prevents active fibroplasia in CCl4-treated rats. Pharmacol Res. 1992 Jan;25(1):87-93.

65. Marchi S, Polloni A, Costa F, Bellini M, Bonifazi V, Tumino E, et al. Liver triglyceride accumulation after chronic ethanol administration: a possible protective role of metadoxina and ubiquinone. Int J Tissue React. 1990;12(4):247-50.

66. Hagymási K, Blázovics A, Lengyel G, Lugasi A, Fehér J. [Investigation of redox homeostasis of liver in experimental and human studies]. Acta Pharm Hung. 2004;74(1):51-63. 
67. Kaul N, Agrawal H, Patil B, Kakad A, Dhaneshwar SR. Application of stability-indicating HPTLC method for quantitative determination of metadoxine in pharmaceutical dosage form. Farm Soc Chim Ital 1989. 2005 Apr;60(4):351-60.

68. Gutiérrez-Ruiz MC, Bucio L, Correa A, Souza V, Hernández E, Gómez-Quiroz LE, et al. Metadoxine prevents damage produced by ethanol and acetaldehyde in hepatocyte and hepatic stellate cells in culture. Pharmacol Res. 2001 Nov;44(5):431-6.

69. Yang YM, Kim HE, Ki SH, Kim SG. Metadoxine, an ion-pair of pyridoxine and L-2-pyrrolidone-5carboxylate, blocks adipocyte differentiation in association with inhibition of the PKA-CREB pathway. Arch Biochem Biophys. 2009 Aug 15;488(2):91-9.

70. Lü Y, Kang Z, Liu Y, Li T, Xiao Y. Pharmacokinetics of metadoxine for injection after repeated doses in healthy volunteers. Chin Med J (Engl). 2007 Jan 20;120(2):166-8.

71. Minushkin ON, Maslovskii LV, Bukshuk AA. [The use of hepatic protectors in clinical practice]. Zh Nevrol Psikhiatr Im S S Korsakova. 2012;112(10 Pt 2):67-72.

72. Safonova SA, Gershanovich ML. [Role of metadoxyl in the treatment of the hepatotoxic effects of cytostatics]. Vopr Onkol. 2005;51(5):599-600.

73. Stefanini GF, Addolorato G, Caputo F, Bernardi M, Gasbarrini G. Treatment of alcoholic fatty liver: is the metabolic effect of metadoxine the only reason for improved liver function? J Hepatol. 1999 Apr;30(4):739-40.

74. Iakovlev VA. [The treatment of alcoholism with metadoxil]. Voen Med Zh. 1999 Oct;320(10):57-9.

75. Baldacci M, Catalani R, Bartoli C, Mura U. Effects of pyridoxine-pyrrolidone-carboxylate on hepatic adenosine triphosphate levels in rats. Boll Della Soc Ital Biol Sper. 1982 Dec 30;58(24):1643-9.

76. Di Paolo N, De Mia M, Gaggiotti E. [Metadoxine in the treatment of vomiting in uremic patients under dialysis treatment]. Clin Ter. 1984 Aug 15;110(3):221-9.

77. Sergiacomo L, Ciancaglini R, Orlando D, Delle Monache G, Pesa O. [Treatment of alcoholic hepatic steatosis with metadoxine. Preliminary results on the evaluation of the effects of the drug by an ultrasonographic study]. Clin Ter. 1986 Oct 31;119(2):133-41.

78. Calabrese V, de Bernardis E, Rizza V. [Metadoxine in the control of oxidative stress caused by acute and chronic ethanol poisoning]. Boll Della Soc Ital Biol Sper. 1986 Nov 30;62(11):1357-63.

79. Carboni MA, Corsa R. [Therapeutic use of metadoxine in alcohol-related mental and behavioral disorders]. Clin Ter. 1987 Dec 31;123(6):469-73.

80. Goh ET, Morgan MY. Review article: pharmacotherapy for alcohol dependence - the why, the what and the wherefore. Aliment Pharmacol Ther. 2017 Apr;45(7):865-82.

81. Testino G, Leone S, Borro P. Treatment of alcohol use disorder patients affected by liver cirrhosis and/or hepatocellular carcinoma awaiting liver transplantation. Minerva Med. 2016 Aug;107(4):223-38.

82. Buoli M, Serati M, Cahn W. Alternative pharmacological strategies for adult ADHD treatment: a systematic review. Expert Rev Neurother. 2016;16(2):131-44.

83. Borro P, Leone S, Testino G. Liver Disease and Hepatocellular Carcinoma in Alcoholics: The Role of Anticraving Therapy. Curr Drug Targets. 2016;17(2):239-51. 
84. Váli L, Blázovics A, Fehér J. [The therapeutic effect of metadoxine on alcoholic and non-alcoholic steatohepatitis]. Orv Hetil. 2005 Nov 20;146(47):2409-14.

85. Lheureux P, Penaloza A, Gris M. Pyridoxine in clinical toxicology: a review. Eur J Emerg Med Off J Eur Soc Emerg Med. 2005 Apr;12(2):78-85.

86. Hagymási K, Blázovics A. [Antioxidants in liver protection]. Orv Hetil. 2004 Jul 4;145(27):1421-5.

87. Fehér J, Lengyel G. A new approach to drug therapy in non-alcoholic steatohepatitis (NASH). J Int Med Res. 2003 Dec;31(6):537-51.

88. Stickel F, Hoehn B, Schuppan D, Seitz HK. Review article: Nutritional therapy in alcoholic liver disease. Aliment Pharmacol Ther. 2003 Aug 15;18(4):357-73.

89. Pár A. [Treatment of alcoholic liver diseases. Abstinence, nutritional support, drug therapy, liver transplantation]. Orv Hetil. 2000 Apr 16;141(16):827-33.

90. Gessa GL. [Guidelines for the drug therapy of alcoholism]. Recenti Prog Med. 1990 Mar;81(3):1715.

91. Santoni S, Corradini P, Zocchi M, Camarri F. [Metadoxine in alcohol-related pathology]. Clin Ter. 1989 Jul 31;130(2):115-22.

92. Leggio L, Kenna GA, Ferrulli A, Zywiak WH, Caputo F, Swift RM, et al. Preliminary findings on the use of metadoxine for the treatment of alcohol dependence and alcoholic liver disease. Hum Psychopharmacol. 2011 Dec;26(8):554-9.

93. Babinets LS, Kytsai KY, Kotsaba YY, Halabitska IM, Melnyk NA, Semenova IV, et al. Improvement of the complex medical treatment for the patients with chronic biliary pancreatitis. Wiadomosci Lek Wars Pol 1960. 2017;70(2):213-6.

94. Pal'tsev AI, Sharapov IV, Gorbunova EN, Khomchenko TN, Kurganova IV, Soldatova GS, et al. [Non-alcoholic fatty liver disease: age peculiarities, breakthrough in pathogenetic therapy]. Eksp Klin Gastroenterol Exp Clin Gastroenterol. 2009;(8):19-25.

95. Mancinella A. [Steatosis and fibrosis: first stage of liver damage induced by chronic alcoholism. Our experience in 100 cases]. Clin Ter. 1991 Apr 15;137(1):29-38.

96. Sil'vestrova SI, Fedotova SI, Drozdov TF, Petrakov AV. [Dynamics of antipirin test at patients with alcoholic liver disease on the background of metadoksin drug receiving]. Eksp Klin Gastroenterol Exp Clin Gastroenterol. 2011;(6):32-7.

97. Rizzo A, Breda A, Moretto F, Pace M, Dotta C, Gelso E, et al. [Therapeutic use of metadoxine in chronic alcoholism. Double blind study of patients in a department of general medicine]. Clin Ter. 1993 Mar;142(3):243-50.

98. Manor I, Rubin J, Daniely Y, Adler LA. Attention benefits after a single dose of metadoxine extended release in adults with predominantly inattentive ADHD. Postgrad Med. 2014 Sep;126(5):7-16.

99. Corsini G, Gelso E, Giuliano G. [Effects of metadoxine on main biohumoral changes induced by chronic alcoholism]. Clin Ter. 1992 Mar;140(3):251-7.

100. Díaz Martínez MCLR, Díaz Martínez A, Villamil Salcedo V, Cruz Fuentes C. Efficacy of metadoxine in the management of acute alcohol intoxication. J Int Med Res. 2002 Feb;30(1):44-51. 
101. Higuera-de la Tijera F, Servín-Caamaño AI, Cruz-Herrera J, Serralde-Zúñiga AE, Abdo-Francis JM, Gutiérrez-Reyes G, et al. Treatment with metadoxine and its impact on early mortality in patients with severe alcoholic hepatitis. Ann Hepatol. 2014 Jun;13(3):343-52.

102. Higuera-de la Tijera F, Servín-Caamaño AI, Serralde-Zúñiga AE, Cruz-Herrera J, Pérez-Torres E, Abdo-Francis JM, et al. Metadoxine improves the three- and six-month survival rates in patients with severe alcoholic hepatitis. World J Gastroenterol. 2015 Apr 28;21(16):4975-85.

103. Shpilenya LS, Muzychenko AP, Gasbarrini G, Addolorato G. Metadoxine in acute alcohol intoxication: a double-blind, randomized, placebo-controlled study. Alcohol Clin Exp Res. 2002 Mar;26(3):340-6.

104. Szabo G, Mandrekar P. Focus On: Alcohol and the Liver. Alcohol Res Health. 2010;33(1-2):87-96.

105. Caballería J, Parés A, Brú C, Mercader J, García Plaza A, Caballería L, et al. Metadoxine accelerates fatty liver recovery in alcoholic patients: results of a randomized double-blind, placebocontrol trial. Spanish Group for the Study of Alcoholic Fatty Liver. J Hepatol. 1998 Jan;28(1):5460 .

106. Shenoy KT, Balakumaran LK, Mathew P, Prasad M, Prabhakar B, Sood A, et al. Metadoxine Versus Placebo for the Treatment of Non-alcoholic Steatohepatitis: A Randomized Controlled Trial. J Clin Exp Hepatol. 2014 Jun;4(2):94-100.

107. Calabrese V, Ragusa N, Rizza V. Effect of pyrrolidone carboxylate (PCA) and pyridoxine on liver metabolism during chronic ethanol intake in rats. Int J Tissue React. 1995;17(1):15-20.

108. Widmer H, Lemos JR, Treistman SN. Ethanol reduces the duration of single evoked spikes by a selective inhibition of voltage-gated calcium currents in acutely dissociated supraoptic neurons of the rat. J Neuroendocrinol. 1998 Jun;10(6):399-406.

109. Wang X, Wang G, Lemos JR, Treistman SN. Ethanol directly modulates gating of a dihydropyridine-sensitive $\mathrm{Ca} 2+$ channel in neurohypophysial terminals. J Neurosci Off J Soc Neurosci. 1994 Sep;14(9):5453-60.

110. Lobo IA, Harris RA. GABAA receptors and alcohol. Pharmacol Biochem Behav. 2008 Jul;90(1):90-4.

111. Davies M. The role of GABAA receptors in mediating the effects of alcohol in the central nervous system. J Psychiatry Neurosci JPN. 2003 Jul;28(4):263-74.

112. Sullivan EV, Harris RA, Pfefferbaum A. Alcohol's Effects on Brain and Behavior. Alcohol Res Health. 2010;33(1-2):127-43.

113. Leslie SW, Brown LM, Dildy JE, Sims JS. Ethanol and neuronal calcium channels. Alcohol Fayettev N. 1990 Jun;7(3):233-6.

114. Peng Z, Borea PA, Varani K, Wilder T, Yee H, Chiriboga L, et al. Adenosine signaling contributes to ethanol-induced fatty liver in mice. J Clin Invest. 2009 Mar;119(3):582-94.

115. Nagy J. Alcohol Related Changes in Regulation of NMDA Receptor Functions. Curr Neuropharmacol. 2008 Mar;6(1):39-54.

116. Willcutt EG. The prevalence of DSM-IV attention-deficit/hyperactivity disorder: a meta-analytic review. Neurother J Am Soc Exp Neurother. 2012 Jul;9(3):490-9. 
117. Froehlich TE, Lanphear BP, Epstein JN, Barbaresi WJ, Katusic SK, Kahn RS. Prevalence, recognition, and treatment of attention-deficit/hyperactivity disorder in a national sample of US children. Arch Pediatr Adolesc Med. 2007 Sep;161(9):857-64.

118. McClure I. ADHD is a behavioural construct, not a psychiatric condition. BMJ. 2013 Nov 27;347:f7071.

119. Reddy DS. Current pharmacotherapy of attention deficit hyperactivity disorder. Drugs Today Barc Spain 1998. 2013 Oct;49(10):647-65.

120. Wilens TE, Morrison NR, Prince J. An update on the pharmacotherapy of attentiondeficit/hyperactivity disorder in adults. Expert Rev Neurother. 2011 Oct;11(10):1443-65.

121. De Sousa A, Kalra G. Drug therapy of attention deficit hyperactivity disorder: current trends. Mens Sana Monogr. 2012 Jan;10(1):45-69.

122. Garnock-Jones KP, Keating GM. Atomoxetine: a review of its use in attention-deficit hyperactivity disorder in children and adolescents. Paediatr Drugs. 2009;11(3):203-26.

123. Ledbetter M. Atomoxetine: a novel treatment for child and adult ADHD. Neuropsychiatr Dis Treat. 2006 Dec;2(4):455-66.

124. Adesman AR. The Diagnosis and Management of Attention-Deficit/Hyperactivity Disorder in Pediatric Patients. Prim Care Companion J Clin Psychiatry. 2001;3(2):66-77.

125. Fallu A, Richard C, Prinzo R, Binder C. Does OROS-methylphenidate improve core symptoms and deficits in executive function? Results of an open-label trial in adults with attention deficit hyperactivity disorder. Curr Med Res Opin. 2006 Dec;22(12):2557-66.

126. Manor I, Newcorn JH, Faraone SV, Adler LA. Efficacy of metadoxine extended release in patients with predominantly inattentive subtype attention-deficit/hyperactivity disorder. Postgrad Med. 2013 Jul;125(4):181-90.

127. Manor I, Ben-Hayun R, Aharon-Peretz J, Salomy D, Weizman A, Daniely Y, et al. A randomized, double-blind, placebo-controlled, multicenter study evaluating the efficacy, safety, and tolerability of extended-release metadoxine in adults with attention-deficit/hyperactivity disorder. J Clin Psychiatry. 2012 Dec;73(12):1517-23.

128. Edden RAE, Crocetti D, Zhu H, Gilbert DL, Mostofsky SH. Reduced GABA concentration in attention-deficit/hyperactivity disorder. Arch Gen Psychiatry. 2012 Jul;69(7):750-3.

129. Nagamitsu S, Yamashita Y, Tanigawa H, Chiba H, Kaida H, Ishibashi M, et al. Upregulated GABA Inhibitory Function in ADHD Children with Child Behavior Checklist-Dysregulation Profile: 123IIomazenil SPECT Study. Front Psychiatry [Internet]. 2015 Jun 2 [cited 2017 Dec 10];6. Available from: https://www.ncbi.nlm.nih.gov/pmc/articles/PMC4451796/

130. Carlsson ML. On the role of cortical glutamate in obsessive-compulsive disorder and attentiondeficit hyperactivity disorder, two phenomenologically antithetical conditions. Acta Psychiatr Scand. 2000 Dec;102(6):401-13.

131. Perlov E, Philipsen A, Hesslinger B, Buechert M, Ahrendts J, Feige B, et al. Reduced cingulate glutamate/glutamine-to-creatine ratios in adult patients with attention deficit/hyperactivity disorder - a magnet resonance spectroscopy study. J Psychiatr Res. 2007 Dec;41(11):934-41.

132. Antonelli T, Carlà V, Lambertini L, Moroni F, Bianchi C. Pyroglutamic acid administration modifies the electrocorticogram and increases the release of acetylcholine and GABA from the guinea-pig cerebral cortex. Pharmacol Res Commun. 1984 Feb;16(2):189-97. 
133. Wilens TE, Martelon M, Joshi G, Bateman C, Fried R, Petty C, et al. Does ADHD Predict Substance Use Disorders? A 10-year Follow-up Study of Young Adults With ADHD. J Am Acad Child Adolesc Psychiatry. 2011 Jun;50(6):543-53.

134. Zulauf CA, Sprich SE, Safren SA, Wilens TE. The complicated relationship between attention deficit/hyperactivity disorder and substance use disorders. Curr Psychiatry Rep. 2014 Mar;16(3):436.

135. Bukstein O. Substance abuse in patients with attention-deficit/hyperactivity disorder. Medscape J Med. 2008 Jan 31;10(1):24.

136. Wilens TE, Adler LA, Tanaka Y, Xiao F, D'Souza DN, Gutkin SW, et al. Correlates of alcohol use in adults with ADHD and comorbid alcohol use disorders: exploratory analysis of a placebocontrolled trial of atomoxetine. Curr Med Res Opin. 2011 Dec;27(12):2309-20.

137. Zhang Z, Xu X, Ni H. Small studies may overestimate the effect sizes in critical care meta-analyses: a meta-epidemiological study. Crit Care Lond Engl. 2013 Jan 9;17(1):R2.

138. Mao Y-M, Zeng M, Li Y-M, Wang B-Y, Shang J, Shi R-H, et al. [Capsule metadoxine in the treatment of alcoholic liver disease: a randomized, double-blind, placebo-controlled, multicenter study]. Zhonghua Gan Zang Bing Za Zhi Zhonghua Ganzangbing Zazhi Chin J Hepatol. 2009 Mar;17(3):213-6.

139. Vedrova NN, Gnezdilova NI. [Metadoxyl in combined treatment of alcohol damage to the liver]. Klin Med (Mosk). 2001;79(4):56-8. 
Figures and Legends:
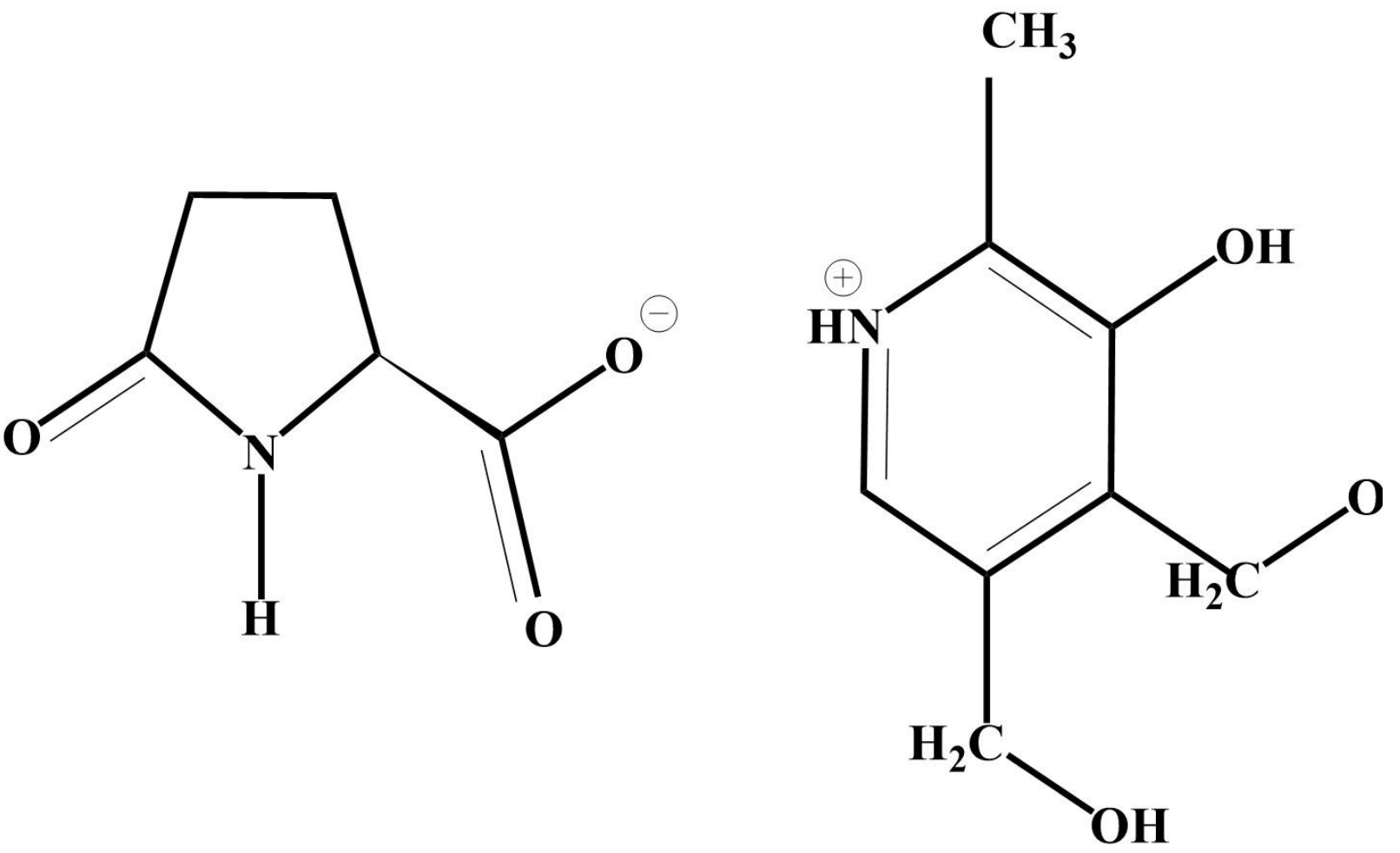

Figure 1: Chemical formula of metadoxine. Metadoxine is composed of pyroglutamic acid (left) and vitamin B6 (right). Both molecules are electrically linked via a salt bridge (cation and anion). 
Amino acid metabolisms

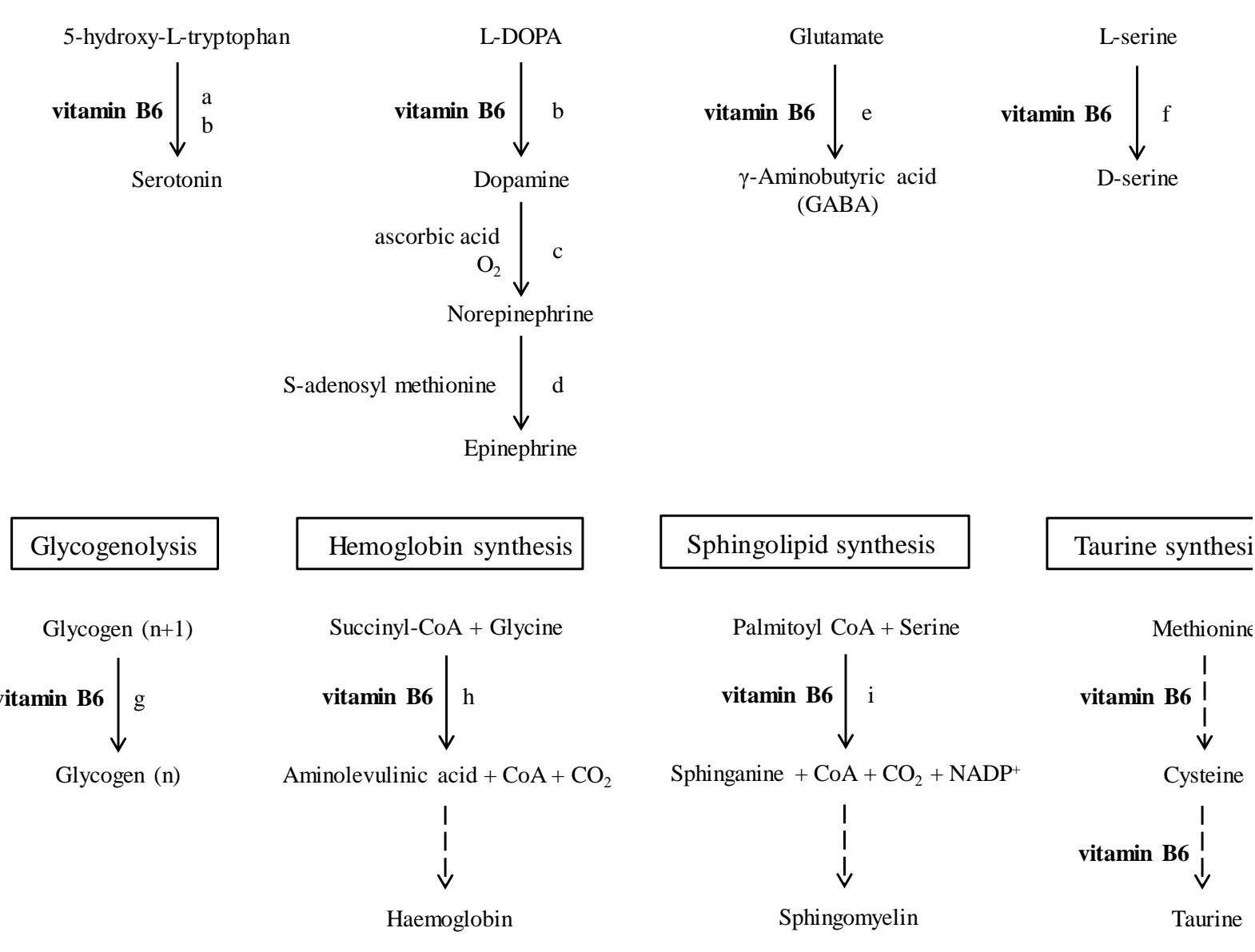

Figure 2: The role of pyridoxal 5'-phosphate (active form of vitamin B6) in different metabolic pathways. The active form of vitamin B6, pyridoxal 5'-phosphate, is required for the syntheses of neurotransmitters, sphingolipids, haemoglobin and taurine, as well as for glycogenolysis. Continuous arrows represent direct products while dashed arrows represent the need for several chemical reactions (not detailed). L-DOPA: L-3,4-dihydroxyphenylalanine, CoA: coenzyme A, NADP: nicotinamide adenine dinucleotide phosphate. a: 5hydroxytryptophan decarboxylase, b: aromatic L-amino acid decarboxylase, c: dopamine- $\beta$ hydroxylase, d: phenylethanolamine $\mathrm{N}$-methyltransferase, e: glutamate decarboxylase, f: serine racemase, g: glycogen phosphorylase, h: aminolevulinic acid synthase, i: serine palmitoyltransferase. 


\section{Glutamate}

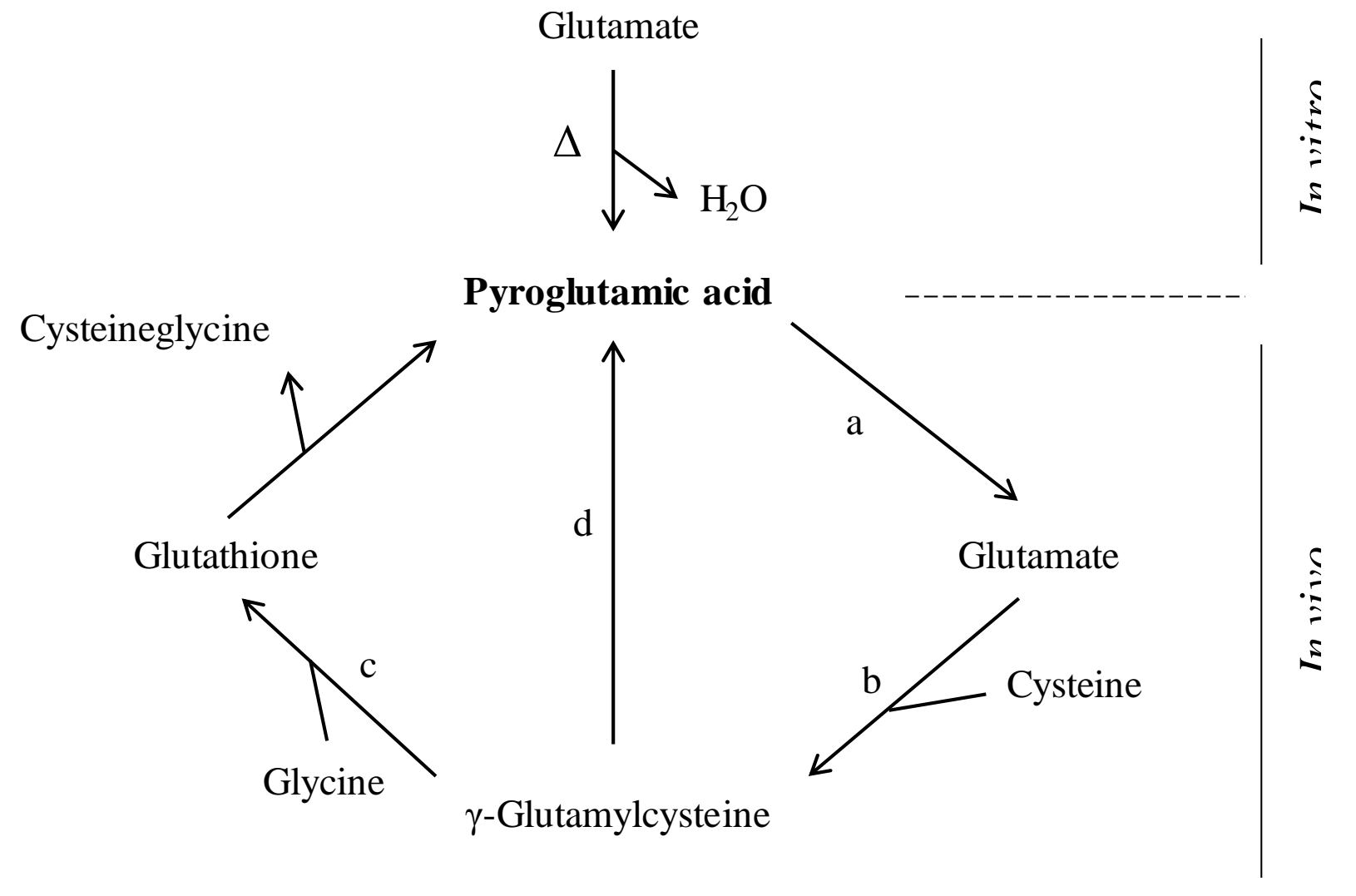

Figure 3: The role of pyroglutamic acid in both glutamate and glutathione metabolisms. Pyroglutamic acid can be obtained in vitro by heating glutamate to $180^{\circ} \mathrm{C}$, resulting in a loss of one water molecule (top). In vivo, pyroglutamic acid is found at the centre of the glutamate/glutathione cycle (bottom). Glutathione exerts a negative feedback on $\gamma$-glutamylcysteine synthase (not drawn). The small triangle represents heating. a: 5-oxoprolinase, b: $\gamma$-glutamylcysteine synthase, c: glutathione synthase, $d: \gamma$-glutamylcysteine cyclotransferase. 


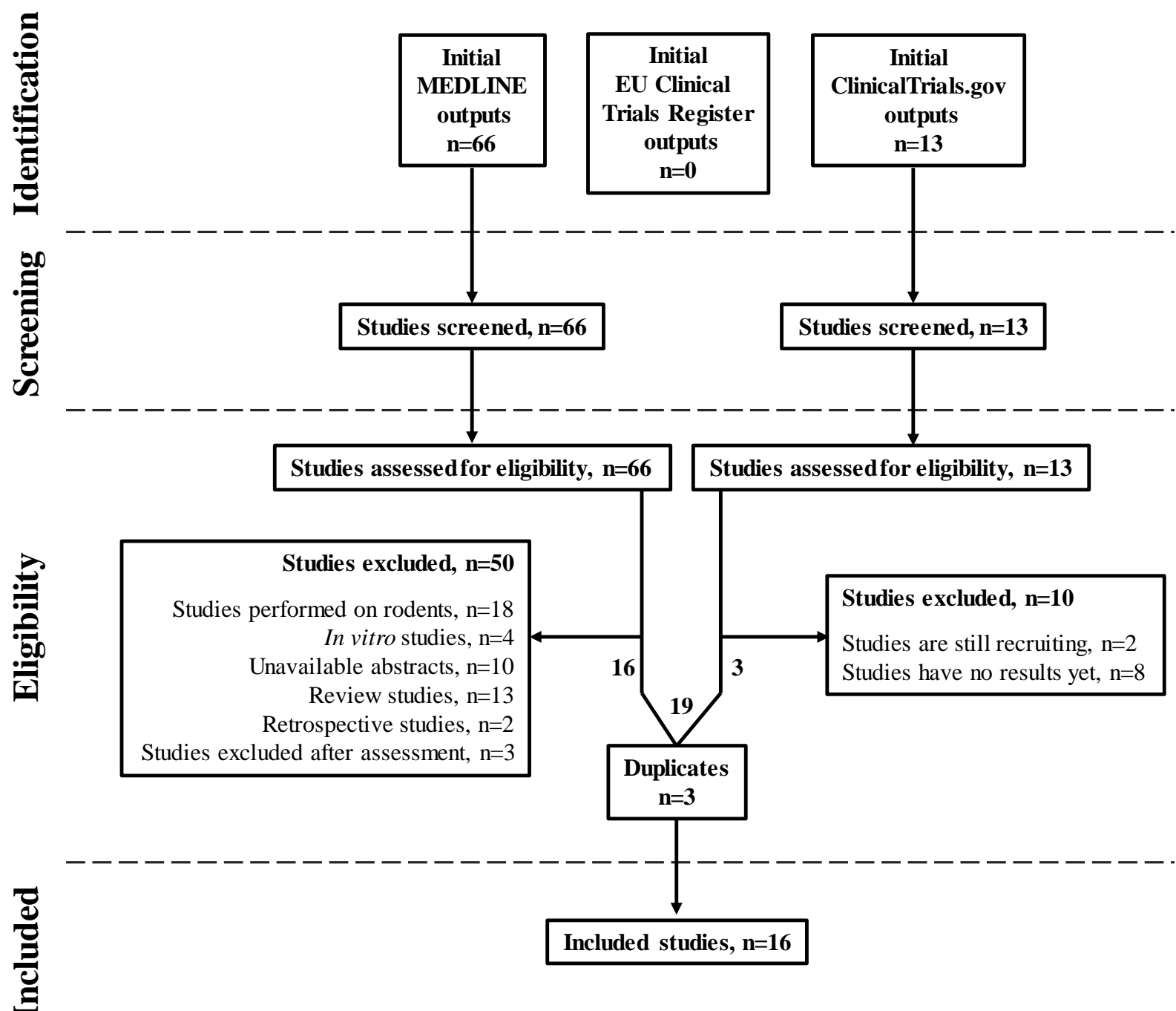

Figure 4: Flow diagram of study design. Identification was performed late July 2017. 


\begin{tabular}{|c|c|c|c|c|c|c|}
\hline Studies & Locations & Pathologies & Type of studies & Number of patients & Regimen & Main outcomes \\
\hline $\begin{array}{l}\text { Higuera-de la Tijera et al, } \\
2015[102]\end{array}$ & Mexico & Alcoholic hepatitis & Randomized, open-label trial & 67 metadoxine, 68 controls & $\begin{array}{l}1500 \mathrm{mg} / \mathrm{day} \text {, for } 30 \\
\text { days }\end{array}$ & $\begin{array}{l}\text {-Improved survival rates after } 3 \text { and } 6 \text { months of treatment. } \\
\text {-Greater abstinence. }\end{array}$ \\
\hline Shenoy et al, 2014 [106] & India & Non-alcoholic hepatitis & $\begin{array}{l}\text { Randomized, double blind, } \\
\text { multicentre trial }\end{array}$ & 75 metadoxine, 59 controls & $\begin{array}{l}1000 \mathrm{mg} / \mathrm{day}, \text { for } \\
112 \text { days }\end{array}$ & $\begin{array}{l}\text {-Improvement of steatosis. } \\
\text {-Safety and tolerability of metadoxine is similar to } \\
\text { placebo. } \\
\text {-Negative results on liver histology. }\end{array}$ \\
\hline Manor et al, 2014 [98] & Israel & Inattentive ADHD & $\begin{array}{l}\text { Randomized, double blind, } \\
\text { single-centre trial }\end{array}$ & 34 metadoxine, 35 controls & $\begin{array}{l}0-1400 \mathrm{mg} \text { once a } \\
\text { week, for } 3 \text { weeks }\end{array}$ & $\begin{array}{l}-700 \mathrm{mg} \text { is ineffective. } \\
-1400 \mathrm{mg} \text { improves attention. } \\
\text {-Safety and tolerability of metadoxine is similar to } \\
\text { placebo. }\end{array}$ \\
\hline $\begin{array}{l}\text { Higuera-de la Tijera } \text { et al, } \\
\text { 2014[101] }\end{array}$ & Mexico & Alcoholic hepatitis & Randomized, open-label trial & 35 metadoxine, 35 controls & $\begin{array}{l}1500 \mathrm{mg} / \mathrm{day} \text {, for } 30 \\
\text { days }\end{array}$ & $\begin{array}{l}\text {-Improved survival rates after } 3 \text { and } 6 \text { months of treatment. } \\
\text {-Better response to treatment usingmetadoxine. } \\
\text {-Adverse events are similar in both groups. }\end{array}$ \\
\hline Manor et al, 2013 [126] & Israel & Inattentive ADHD & $\begin{array}{l}\text { Randomized, double-blind, } \\
\text { multisite trial }\end{array}$ & 60 metadoxine, 60 controls & $\begin{array}{l}1400 \mathrm{mg} / \mathrm{day}, \text { for } 42 \\
\text { days }\end{array}$ & $\begin{array}{l}\text {-Metadoxine is only efficacious for treating inattention in } \\
\text { adults with predominantly inattentive ADHD, but not in } \\
\text { adults with other forms of ADHD. }\end{array}$ \\
\hline Manor et al, $2012[127]$ & Israel & ADHD & $\begin{array}{l}\text { Randomized, double-blind, } \\
\text { multisite trial }\end{array}$ & 60 metadoxine, 60 controls & $\begin{array}{l}1400 \mathrm{mg} / \text { day, for } 42 \\
\text { days }\end{array}$ & $\begin{array}{l}\text {-Metadoxine is well tolerated. } \\
\text {-Metadoxine is efficient in treating adults with ADHD. }\end{array}$ \\
\hline Sil'vestrova et al, 2011 [96] & Russia & Alcohol liver disease & Non-randomized study & 36 patients, no controls. & $\begin{array}{l}500 \mathrm{mg} / \text { day, for } 28 \\
\text { days }\end{array}$ & -Improvement of drug-metabolising liver function. \\
\hline Mao et al, 2009 [138] & China & Alcohol liver disease & $\begin{array}{l}\text { Randomized, double blind, } \\
\text { multicentre trial }\end{array}$ & 126 metadoxine, 128 controls & $\begin{array}{l}1500 \mathrm{mg} / \mathrm{day} \text {, for } 42 \\
\text { days }\end{array}$ & $\begin{array}{l}\text {-Improvement of liver functions only in abstinent patients. } \\
\text {-Adverse events are similar in both groups. } \\
\text {-Metadoxine improves liver to spleen ratios. }\end{array}$ \\
\hline Guerrini et al, $2006[2]$ & Italy & Alcohol dependence & $\begin{array}{l}\text { Non-randomized, follow-up } \\
\text { study }\end{array}$ & 58 metadoxine, 102 controls & $\begin{array}{l}1000 \mathrm{mg} / \mathrm{day} \text {, for } 90 \\
\text { days }\end{array}$ & $\begin{array}{l}\text {-Better rate of complete abstinence with metadoxine. } \\
\text {-Significantly less drop-outs with metadoxine. }\end{array}$ \\
\hline Shpileny a et al, 2002 [103] & Russia & $\begin{array}{l}\text { Acute alcohol } \\
\text { intoxication }\end{array}$ & $\begin{array}{l}\text { Randomized, double blind, } \\
\text { multicentre trial }\end{array}$ & 29 metadoxine, 29 controls & $900 \mathrm{mg}$, i.v., once & $\begin{array}{l}\text {-Faster elimination of ethanol. } \\
\text {-Faster recovery rate. }\end{array}$ \\
\hline Díaz Martínez et al, 2002 [100] & Mexico & $\begin{array}{l}\text { Acute alcohol } \\
\text { intoxication }\end{array}$ & Randomized, open-label trial & 26 metadoxine, 26 controls & $\begin{array}{l}300-600 \mathrm{mg}, i . v . \\
\text { once }\end{array}$ & $\begin{array}{l}\text {-Improvement of intoxication. } \\
\text {-Acceleration of alcohol clearance. }\end{array}$ \\
\hline Vedrova et al, $2001[139]$ & Russia & Alcohol liver disease & Not specified & 20 metadoxine, 12 controls & $\begin{array}{l}1500-2000 \mathrm{mg} / \mathrm{day}, \\
\text { for } 30 \text { days }\end{array}$ & $\begin{array}{l}\text {-Normalisation of liver functions. } \\
\text {-Metadoxine does not induce adverse events. }\end{array}$ \\
\hline Caballería et al, $1998[105]$ & Spain & Fatty liver disease & $\begin{array}{l}\text { Randomized, double blind, } \\
\text { multicentre trial }\end{array}$ & 69 metadoxine, 67 controls & $\begin{array}{l}1500 \mathrm{mg} / \mathrm{day} \text {, for } 90 \\
\text { days }\end{array}$ & $\begin{array}{l}\text {-Faster improvement of liver functions with metadoxine. } \\
\text {-Amelioration of steatosis. } \\
\text {-Lower proportion of patients with signs of steatosis. }\end{array}$ \\
\hline Rizzo et al, 1993 [97] & Italy & Chronic alcoholism & Randomized, double blind & $\begin{array}{l}60 \text { enrolled patients, metadoxine } \\
\text { and placebo }(\mathrm{n}=?)\end{array}$ & unknown & $\begin{array}{l}\text {-Better abstinence symptomatology. } \\
\text {-Lower need for benzodiazep ine/neurolep tic therapy. }\end{array}$ \\
\hline Corsini et al, $1992[99]$ & Italy & Chronic alcoholism & $\begin{array}{l}\text { Randomized, open-label, } \\
\text { multicentre trial }\end{array}$ & 52 metadoxine, 20 controls & $\begin{array}{l}1000 \mathrm{mg} / \mathrm{day}, \text { for } 60 \\
\text { days }\end{array}$ & $\begin{array}{l}\text {-Significant reduction of mean corpuscular volume. } \\
\text {-Improvement of enzy matic functions (liver). } \\
\text {-No metadoxine-induced adverse event. }\end{array}$ \\
\hline Bono et al, 1991 & Italy & Chronic alcoholism & Randomized, double blind & 20 metadoxine, 20 controls & $\begin{array}{l}1800 \mathrm{mg} / \mathrm{day} \\
\text { infused, for } 10 \text { days }\end{array}$ & $\begin{array}{l}\text {-Better alcohol abstinence. } \\
\text {-Reduction for the need of benzodiazepines. }\end{array}$ \\
\hline
\end{tabular}

Table 1: Basic characteristics and main outcome(s) of clinical trials investigating the effects

of metadoxine. Note that some trials did not compare patients receiving metadoxine to control patients. Also, some regimen were not known. The physiopathologies of patients could be divided into two major categories: patients with liver disorders or patients with central nervous system disorders. ADHD: attention deficit and hyperactivity disorder. 


\begin{tabular}{|c|c|c|c|c|c|c|}
\hline Studies & $\begin{array}{c}\text { Random sequence } \\
\text { generation }\end{array}$ & $\begin{array}{c}\text { Allocation } \\
\text { concealment }\end{array}$ & Blinding & $\begin{array}{l}\text { Accounting of patients } \\
\text { and ou tcome vents }\end{array}$ & $\begin{array}{l}\text { Selective } \\
\text { reporting }\end{array}$ & Ove rall risk of bias \\
\hline $\begin{array}{l}\text { Higuera-de la Tijera et al, } 20 \\
{[102]}\end{array}$ & & & & & & \\
\hline Shenoy et al, 2014 [106] & & & & & & \\
\hline Manor et al, 2014 [98] & & & & & & \\
\hline $\begin{array}{l}\text { Higuera-de la Tijera et al, } 20 \\
{[101]}\end{array}$ & & & & & & \\
\hline Manor et al, 2013 [126] & & & & & & \\
\hline Manor et al, $2012[127]$ & & & & & & \\
\hline Sil'vestrova et al, 2011 [96] & & $?$ & ? & & & \\
\hline Mao et al, 2009 [138] & & & & & & \\
\hline Guerrini et al, 2006 [2] & & $?$ & ? & & & \\
\hline Shpilenya et al, 2002 [103] & & & & & & \\
\hline Díaz Martínez et al, 2002 & & & & & & \\
\hline Vedrova et al, 2001 [139] & ? & $?$ & $?$ & & & \\
\hline Caballería et al, 1998 [105] & & & & & & \\
\hline Rizzo et al, 1993 [97] & & & & & & \\
\hline Corsini et al, 1992 [99] & & & & & & \\
\hline Bono et al, 1991 [35] & & & & & & \\
\hline
\end{tabular}

Table 2: Risk of bias across included studies. Low (white), medium (grey), high (black) and unknown (?) risks of bias. 


\begin{tabular}{|c|c|c|c|}
\hline Physiopathology & $\begin{array}{c}\text { ClinicalTrials.gov } \\
\text { identifier }\end{array}$ & $\begin{array}{c}\text { Status } \\
\text { (as of July 2017) }\end{array}$ & $\begin{array}{c}\text { Published } \\
\text { findings }\end{array}$ \\
\hline \multirow{2}{*}{$\begin{array}{l}\text { Non-alcoholic } \\
\text { steatohepatitis }\end{array}$} & NCT02541045 & \multirow{2}{*}{ Still recruiting } & \\
\hline & NCT02051842 & & \\
\hline Alcoholic hepatitis & NCT02161653 & $\begin{array}{c}\text { Completed } \\
\text { Available results }\end{array}$ & [105] \\
\hline $\begin{array}{c}\text { Alcoholism } \\
\text { Alcohol liver disease }\end{array}$ & NCT01504295 & \multirow{3}{*}{ Completed } & \\
\hline $\begin{array}{l}\text { Fatty liver disease } \\
\text { Alcoholic hepatitis }\end{array}$ & NCT02019056 & & \\
\hline $\begin{array}{c}\text { ADHD, } \\
\text { Fragile X syndrome }\end{array}$ & NCT02126995 & & \\
\hline \multirow{6}{*}{ ADHD } & NCT00995085 & \multirow{2}{*}{$\begin{array}{c}\text { Completed } \\
\text { Available results }\end{array}$} & \\
\hline & NCT01243242 & & {$[128,129]$} \\
\hline & NCT02189772 & Completed & \\
\hline & NCT01685281 & \multirow{2}{*}{$\begin{array}{c}\text { Completed } \\
\text { Available results }\end{array}$} & [98] \\
\hline & NCT02059642 & & \\
\hline & NCT02477748 & On hold & \\
\hline Healthy volunteers & NCT01933997 & Completed & \\
\hline
\end{tabular}

Table 3: List of all clinical trials investigating metadoxine, registered in the ClinicalTrials.gov database and up to July 2017. Past and current (as of July 2017) clinical trials investigating metadoxine for its potential use in different diseases. Trials are sorted according to pathologies, identification number (ClinicalTrials.gov identifier) and status. Note that a minority of the completed trials have available published results. 